\title{
ATTACHMENT DENIED? THE EXPERIENCE OF SEPARATION FOR LIVE-IN CAREGIVERS' CHILDREN
}

by

Parvin Vahdat, MA, Allameh Tabatabaei University, 2000

\author{
A Major Research Paper \\ Presented to Ryerson University
}

in

partial fulfillment of the requirements for the degree of

\author{
Master of Arts \\ In the program of \\ Immigration and Settlement Studies
}

Toronto, Ontario, Canada, 2011

Parvin Vahdat, 2011 


\section{Author's Declaration}

I hereby declare that I am the sole author of this major research paper.

I authorize Ryerson University to lend this paper to other institutions or individuals for the purpose of scholarly research.

I further authorize Ryerson University to reproduce this paper by photocopying or by other means, in total or in part, at the request of other institutions or individuals for the purpose of scholarly research. 


\title{
ATTACHMENT DENIED? THE EXPERIENCE OF SEPARATION FOR THE LIVE-IN CAREGIVERS' CHILDREN
}

\author{
Parvin Vahdat \\ Master of Arts 2011 \\ Immigration and Settlement Studies \\ Ryerson University
}

\begin{abstract}
The live-in caregivers' non-citizenship status in Canada results in separation from their children.

So far, rare studies have addressed these children and the impacts of separation on them. This paper, through relying on some aspects of attachment theory, discusses the negative impacts of separation on the children of live-in caregivers and argues that race and class inequalities have rendered them invisible in psychological and other scholarly studies. The paper also addresses the problems faced by these children in the countries of origin. Live-in caregivers perform mothering for their children from afar. However, as the result of traditional gender ideology, their transnational mothering is stigmatized there. The stigmatization affects immigrant live-in caregivers and their separated children negatively. The paper calls for removing restrictions that separate children from their immigrant mothers and asks for other changes that improve the lives of these children.
\end{abstract}

Key Words:

Live-in Caregivers' children, Separation, Attachment Theory, Transnational Mothering 


\section{ACKNOWLEDGMENT}

I would like to acknowledge the supervision of Professor Sedef Arat-Koc in the preparation of this paper and thank her for her useful suggestions and critical notions throughout writing this paper.

Special thanks to Professor Anver Saloojee for his support and constructive comments that had an integral role in completing this paper. I would also like to thank Professor Vappu Tyyska for reassuring me of her support and her being there for me.

Finally, I would like to thank my family and friends. I am sure that this paper would not have been completed without their encouragement, help and support. 
To the loving memory of my mother 


\section{Table of Contents:}

INTRODUCTION

THE LIVE-IN CAREGIVERS' PROGRAM AND THE SEPARATION OF MOTHERS AND CHILDREN

The Regulations of the LCP

Lack of Citizenship Status and Separation

ATTACHMENT THEORY AND LIVE-IN CAREGIVERS' CHILDREN

Tenets of Attachment Theory

Critiques of Attachment Theory

Feministic Critics

The Live-in Caregivers' Children; Prolonged and Successive Separations

Attachment Theory and the Employers' Children

TRANSNATIONAL MOTHERING AND LIVE-IN CAREGIVERS' CHILDREN

Stigmatization of Transnational Mothers and its Impacts on the Children

Reunification: the Continuation of the Problems

THE LIVE-IN CAREGIVERS' CHILDREN: WHOSE RESPONSIBILITY?

International Conventions, State Regulations

Recommendations

Conclusion

REFERENCE、 


\section{Introduction}

There has been a. "feminization" of immigrants in recent decades. According to the United Nations (2009), almost half of the 214 million international immigrants in 2009 were women emigrating mainly from the Third World countries. This increase in women's immigration is partly the result of a recent increase in participation in the work force by women in the advanced countries. As patriarchal beliefs associate domestic and care work with women's responsibilities, women's entry into the work force has shaped the nature of the solutions found for child and other forms of care, traditionally provided by female family members. To meet this need, one of the options in Canada has been to hire foreign domestic workers through the Live-in Caregiver Program (LCP), implemented by Citizenship and Immigration Canada ( $\mathrm{ClC}$ ). Lack or shortage of affordable child care, and the absence of help from male partners force working women to turn over the care of their children to live-in caregivers (Ehrenreich \& Hochschild 2003; Tyyska 2001).

Most live-in caregivers, though not officially stated, are mothers but they are not allowed to bring their children with them upon entering Canada. Two specific dimensions of Canada's immigration policies applying to the live-in caregivers make it impossible for them to immigrate to Canada with their families. First, live-in caregivers, unlike other immigrants, receive a temporary work permit which means that they can only arrive as individual workers, rather than with their families; and second, they have to live in their employers' homes (AratKoc 2001; CIC 2010; Cohen 2000; Pratt 2006). The implications of these restrictions are psychological burdens for live-in caregivers and separation for their children. Canada is one of 
the countries that have ratified the United Nations Convention on the Rights of the Child (CRC). According to this convention "States Parties shall ensure that a child shall not be separated from his or her parents against their will" (Article 9; 1). Despite this provision, however, children are separated from their immigrant mothers through Canada's restrictive immigration policies imposed on live-in caregivers.

So far, academics have addressed domestic workers and the LCP from a number of different perspectives. However, reviewing the existing literature reveals how little attention has been paid to live-in caregivers' children. These children are invisible in the media, and are not even discussed by scholars in fields such as psychology where generally, children are the centre of extensive attention, examination and research. The importance of a healthy motherchild relationship and the harmful impacts of separation are particularly pivotal to psychological research on child development. These studies are mainly based on John Bowlby's attachment theory. John Bowlby and his colleague Mary Ainsworth's work is based on their studies of children who had suffered from forced separation as the result of war, hospitalization and institutionalization (Bretherton 1992). As they argue, the separation from, or loss of, the primary caregiver, who is generally the mother, causes serious problems for the children (Ainsworth 1967; Bowlby 1951). These problems are believed to have long lasting effects on children and even influence their adult-life relationships (Ainsworth 1967; Bowlby 1951; 1979). John Bowlby has been criticized for the limitation of his theory, particularly by feminist critics, in terms of the absence of race, class and gender perspectives in his research and analysis (Cleary 1999; Franzblau 1999). Despite criticism, attachment theory is still regarded as important within psychological studies. And although the nature of separation might be 
different from the cases on which Bowlby based his theory, some aspects of attachment theory are relevant to the case of live-in caregivers' children who are separated from their mothers as the result of immigration restrictions. These aspects include physical separation between live-in caregivers and their children, disrupted attachments and successive separations, and the negative emotional and social impacts on children. Though children are pivotal to much psychological research, so far there is hardly any research that has addressed the children of live-in caregivers.

Live-in caregivers contribute significantly to the economy of their countries of origin. Nevertheless their children face social and cultural pressures there. Even though immigrant mothers keep their ties with their children beyond national borders through phone calls, internet and sending gifts, and as such perform "transnational mothering" (Hondagneu-Sotelo 2005; Parrenas 2001), their transnational mothering is disapproved and considered as a way of evading mothering duties (Parrenas 2006). The media highlights the troubled situation of these children and blames their immigrant mothers as the cause of their problems (Parrenas 2003; 2010). Ironically, these reports are mainly published in the Philippines, where the immigrant domestic workers are also celebrated as heroes for their remarkable financial contribution to the country (Parrenas 2003, 41; 2006). But their "heroism" does not ease their conditions. The stigmatization of transnational mothering makes live-in caregivers feel guilty, inadequate and ashamed for being "bad mothers" (Arat-Koc 2001, 26; Isaken et al., 2008, 64). The conflicting assessment of live-in caregivers in public discourse in their home country leaves them confused experiencing two opposite feelings of pride and shame simultaneously (Arat-Koc 2006, 80). 
This problem is not limited to the mothers. It affects their children and further complicates the process of separation for them (Parrenas 2003; 2006; 2010).

This paper focuses on the negative impacts of Canada's immigration policies on the lives of live-in caregivers' children who are separated from their mothers by the regulations of the LCP. After discussing the provisions of the LCP that impose forced separation on mothers and children, the paper examines the impacts of separation on children from a psychological perspective by relying on John Bowlby's attachment theory. Discussing the concepts and critiques of attachment theory, the paper identifies those aspects of the theory which are still relevant to the case of live-in caregivers' children and argues that race and class inequalities have rendered these children to negligence in the field of psychology. The paper then discusses transnational mothering performed by live-in caregivers as a way of coping with and easing the effects of forced separation. In the final section, the paper raises the question "who is responsible" for the needs and the rights of children of migrant live-in caregivers. It identifies different social and political actors at local, national and international levels; assesses what they do or do not do in terms of these responsibilities and concludes with some recommendations and suggestions for the alleviation of their situation.

Even though the research for the paper does not involve any interviews, observations, or experiments, there are still ethical considerations. Relying on basic ethical principles, I was careful that the content of my paper does not offend or have negative implications for the live-in caregivers, their children and the children they take care of. 


\section{The Live-in Caregivers' Program and the Separation of Mothers and Children}

She begged his purchaser to buy herself and her daughter Emily too so they could all stay together, promising to be the best worker he had ever had. She wept and begged to the extent that she was threatened with a whipping, but it was to no avail: 'Then Eliza ran to him; embraced him passionately; kissed him again and again; told him to remember her-all the while her tears falling in the boy's face like rain' (Aptheker 1951, 208; Cited in Anderson 2000, 130).

The sound of the above anecdote seems to come from a long time ago. However it is echoed in the recent memories of contemporary immigrant domestic workers who share the same poignant experience with the slave motherș:

I could not walk up the bus; the driver had to carry me up. I was so weak and faintleaving my kids and not knowing how long it would be before we could be together again (cited in Arat-Koc 2001, 26).

A mother of a 13-year-old boy from Central America who had to leave her son recalled:

I was a single mother and there we were at war I talked it over with my mother and she told me that maybe [thing would be better] on 'the other side'. It was very hard above all to leave the children when they were so small. I would go into the bathroom of the gas station and milk my breasts that overflowed, crying for my babies. Every time I think of it, it makes me sad (cited in Suarez-Orozco et al. 2001, 10).

Separation of mothers from their children is not new. The case has "historical roots and/or close parallels in slavery, contract labor and migrant labor systems such as the one in South Africa under apartheid" (Arat-Koc 2001, 23). Such separation was typically in the coercive systems of labor in the $18^{\text {th }}$ and $19^{\text {th }}$ centuries when "African American slaves and Chinese sojourner labourers were denied the right to form residentially intact families" (HondagneuSotelo \& Avila 2005, 310). The common element of all these systems is maximizing economic productivity at the expense of denying the workers' right of family life (Hondagneu-Sotelo \& Avila 2005). 
The cause for some of the recent separation of mothers from their children is the immigration restrictions, imposed by the receiving countries on the immigrant live-in caregivers. The immigration of live-in caregivers, mainly from developing countries to advanced capitalist countries, is a result of poor economic opportunities in their countries and the increasing participation of women in the workforce in countries like Canada (Cohen 2000; Hodge 2006; Mahon 2005; Parrenas 2003; Pratt 2006; Tyyska 2001). According to Statistics Canada, between 1976 and 2002, the labour force participation of women with children under the age of six has increased from 30 percent to 70 percent (cited in Bushnik 2006, 8). This increase has a corresponding demand for substitution for domestic and care work which is traditionally assumed as women's responsibility. In Canada, child care policy is linked to power divisions both among the three government levels as well as to social class and gender inequalities (Tyyska 2001). The politics associated with these has meant that in Canada the government does not provide families with enough child care services.

As a way of addressing the increasing demand for care work, Citizenship and Immigration Canada $(\mathrm{ClC})$ brings in live-in caregivers through the Live-in Caregiver Program (LCP).Canada has a long history of importing workers for domestic and care work. Historically the immigration of domestic workers was shaped by a racial hierarchy that was based on the proximity of their backgrounds to "white British ideals" (Bakan \& Stasiulis 1994; Ehrereich \& Hochschild 2003; Kelley \& Trebilcock 2000; Pratt 1997). As the numbers of British women migrating as domestic workers declined in the $20^{\text {th }}$ century, the increasing demand for domestic workers led to recruiting women from other European countries. Recruitment of women of color from outside Europe was considered as the "last resort" for Canada (Arat-Koc 1997, 78). 
The adverse economic conditions in the global South, and care demand in countries like

Canada, create an ideal situation for the Live-in Caregiver Program to operate (Hodge 2006, 64). Based on global inequalities and the gender ideology that continues to treat women as . responsible for domestic and care work, women from the Third World countries are pushed to look for care-related job opportunities available in advanced capitalist countries (Hodges 2006; Steil \& England 1997).

\section{The Regulations of the LCP}

Ironically, the very live-in caregivers who immigrate to Canada to perform the reproductive labor and take care of other families are unable to take care of their own family. Two specific aspects of the LCP prevent the immigration of live-in caregivers with their families. First that live-in caregivers receive temporary working permits rather than permanent resident status at the time of their entry to Canada and second, that foreign domestic workers are required to live in their employers' houses (CIC 2010; Cohen 2000; Pratt 2006).

The majority of live-in caregivers, who currently immigrate to Canada, are university educated and eligible to apply through the point system which defines the criteria for permanent residents (Arat-Koc 2006; Cohen 2000; Kelly 2006; Pratt 2006). However, because of the low number of points given to their work as well as the required education and experience provisions, they have to apply through the $L C P$, which is an employment and not immigration program. According to Canadian Council for Refugees:

Temporary work permits were designed to address temporary labour shortages, but are now used to fill permanent labour shortages. This new trend is creating a class of disposable workers who have to accept working conditions that Canadians don't. These workers do not have access to the same rights as permanent residents and Canadian 
citizens, such as the right to choose where they live to change employers without government permission.

Receiving a working visa means lack of citizenship status for live-in caregivers. Formally, citizenship in Canada includes rights, responsibilities and freedom (Canadian Citizenship Act 2009). For immigrants, citizenship also has other substantive dimensions including a sense of belonging and identity, and possibilities for active participation and total integration into the receiving country (Saloojee 2003). Lack of citizenship status deprives live-in caregivers from both the formal and substantive aspect of full citizenship status. Moreover, the specific conditions and requirements attached to the LCP and specifically living far from their immediate families has negative physical and psychological impacts on live-in caregivers (AratKoc 2006; Parrenas 2010; Pratt 2006). The physical burdens are related to the living-in requirement as well as the vulnerability of the legal status of the workers. They include excessive work hours with no overtime pay, sexual abuse and harassment, and substandard living conditions. The psychological burdens include depression, anxiety, nostalgia, isolation and asymmetrical power relationship between live-in caregivers and their employers. Additionally, live-in caregivers' lack of access to organizations or trade unions renders them more vulnerable (Ally 2005; Zarmpka 2000).

\section{Lack of Citizenship Status and Separation}

An extensive review of the literature on live-in caregivers reveals that a recurring theme of concern, to many researchers and scholars has been the direct and indirect implications of the lack of citizenship status. Some studies that address this theme from different approaches include: racial discrimination (Bakan and Stasiulis 1994; Hodge 2006; Parrenas 2001; Steil \& 
England 1997); the physical; emotional and psychological abuse of the live-in caregivers (AratKoc 2001; Cohen 1991 \& 2000; Mirchandani \& Doucet 1999); the impact of the LCP's restrictions on the live-in caregivers' families (Moors 2003; Parrenas 2006; Pratt 2006); domestic workers' lack of organizing and essential associations such as unions (Ally 2005; Zarempka 2000); transnational families (Arat-Koc 2003; Hondagneu-Sotelo \& Avila 2005); economic consequences of remittances and deskilling of live-in caregivers (Kelly 2009; Parenas 2003; 2006; Sherman 1996); the asymmetrical power relationship between the live-in caregivers and their employers (Constable 1999; Parrenas 2001; Pratt 2006) and the invisibility of their efficient reproductive care work (Anderson 2001; Arat-Koc 2006; Hochschild 2007; Parrenas 2003; Tung 2000). Some researchers like Bernhard et al. (2005) have addressed separation and reunification among transnational families with a focus on the role of service providers for these families in Canada. While others like Parrenas (2010) have concentrated on the issue of gender conflicts in these kinds of families in the countries of origin.

One of the most significant implications of the absence of citizenship status for live-in caregivers, who are mothers, is forced separation from their children. Arat-Koc (2001) recognizes separation as an example of emotional violence against the live-in caregivers. While the status and conditions of live-in caregivers have gone under detailed examination by academics, the psychological, social and emotional costs of this separation, particularly on. children, "have been often omitted from the migration balance sheet" (Yeoh and Lam 2003, 1). The invisibility of live-in caregivers' children is one of the clearest gaps in the existing literature on the topic of live-in caregivers. During a research on the children of immigrant domestic workers, Isaksen, Devi and Hochschild (2008) found that discussing these children "seemed to 
many of those involved off limits" (63). One of the main reasons they identify in their study is that those who benefit from these women's migration want the immigration to work.

Except for rare academic research such as the one conducted by Suarez-Orozoc et al. (2001), which examines the experience of separation by the children of immigrant families, the children of migrant live-in caregivers are generally absent from psychological researches and studies. This is despite the fact that there has been specific analysis in the psychological literature that focuses on the impact of forced separation on children. These analyses are mainly based on John Bowlby and his attachment theory. The theory considers a consistent emotional bond as significant and separation as harmful to the emotional health and well-being of children. Even though the case of live-in caregivers' children is relevant for this theory, there is hardly any psychological research that has focused on them and examined the impacts of forced separation on these children so far. Relying on attachment theory, the following chapter discusses how Canada's immigration policies affect live-in caregivers' children by not allowing them to immigrate with their mothers. 


\section{Attachment Theory and Live-in Caregivers' Children}

The case of mothers being forced to separate from their children is neither new nor restricted to live-in caregivers' children. The children of Australian Aboriginals known as the 'Stolen Generation' as well as children of Canadian Aboriginals sent to residential schools are among examples of forced separation of children from their mothers (Tourigny 2007).

European children were also separated from their families during the Second World War

(Tanner \& Inhelder 1971). The latter groups of children were not victims of racial or class

discrimination. In fact the purpose behind this latter example of separation was to protect the children. Nevertheless, psychologists have found that separation left harmful impacts on them too. Observing the impacts of forced separation on children was pivotal to developing John Bowlby's attachment theory. Despite much criticism, attachment theory is still regarded as an important theory in psychology. However even though live-in caregivers' children are a recent instance of forced separation, so far no study has addressed them from this perspective. One reason for the exclusion of these children from psychological research has to do with the individualistic perspective the discipline of psychology tends to take in relation to the understanding and the solution of problems. From a psychological perspective, the problems faced by children would likely be explained by their mothers' and not the society's negligence (Tizard 1991). Moreover, psychology in general and attachment theory in particular, emerge from Western societies and are influenced by class, race and gender inequalities and dominant values in these societies. They mainly tend to take white and middle-class people and their lifestyle as the norm. As such, the astonishing neglect of live-in caregivers' children in

psychological research and discussions essentially reflects the exclusion of their race and class. 
Through discussing the concepts and critiques of attachment theory, this chapter will identify those aspects of the theory that are still relevant to the case of live-in caregivers' children and their experience of forced separation. The problems faced by live-in caregivers' children are determined by economic, social and cultural factors and analyzing them has to go beyond an individualistic perspective. These problems need to be addressed from a wide perspective that involves all responsible parties within the community, society, state and international levels. At the same time discussing these children from attachment theory perspective helps to show how race, class and gender inequalities and other economic and political considerations marginalize a group of children and render them and their needs and rights invisible within academic debates.

\section{Tenets of Attachment Theory}

John Bowlby, the British psychiatrist and psychologist is mainly known for his attachment theory. Through his empirical studies and detailed examination of cases of maladjusted children, Bowlby found a link between these children's behavior and histories of separation or maternal deprivation (Bretherton 1992). His observations of the impacts of separation on the children who were separated from their main caregiver/mother or orphaned as the result of the bombing in Britain, during the Second World War, led to further development of his theory (Bretherton 1992; Holmes, J. 1993). Bowlby also studied the impacts of separation on the hospitalized and institutionalized children. In addition to his studies, research and experiences, John Bowlby's childhood and the family style he was raised by, were also influential in inspiring his professional life and his development of attachment theory (Holmes, J. 1993). To formulate his theory, Bowlby in addition to psychology and psycho 
analysis, relied significantly on concepts from ethology, cybernetics and information processing (Bretherton 1992).

One of the most significant ideas in attachment theory, as defined by John Bowlby, is that between 6 to 30 months, children develop an emotional bond with their main caregiver. Bowlby regards attachment behavior as essential to the infant's survival and argues that through the course of evolution, infants who kept proximity to a caregiver figure managed to survive into reproductive age. Showing anxiety and crying upon separation from the main caregiver are considered as normal in the process of child development (Bowlby 1969). Bowlby argues that attachment, unlike dependency, performs a healthy function and is essential to the life of both children and adults (Bretherton 1992). According to this theory, failure to form an attachment bond or being separated after the bond is formed, has negative impacts on children's behavior and could result in psychopathological problems (John Bowlby 1979, 9).

Similarly important to attachment theory is creating an internal working model that affects relationships with other attachment figures in adulthood. As discussed by Bowlby (1973), infants have two opposite groups of needs. On the one hand, they need protection to feel secure and on the other hand they need independence to explore their environment. If both groups of needs are supplied respectfully by attachment figures, then the child develops an internal working model which considers self as respectful and valued. In contrast, the . internal working model that is shaped by constant rejection of the child, results in regarding self as unworthy or inadequate. According to longitudinal research that supports attachment theory, patterns of relationships for adult people are compatible with the attachment styles and the internal working models that they have developed during childhood (Bretherton 1992; 
Simpson \& Rholes 2010). Studying adult attachment patterns shows that the internal working model influences relationships between siblings, spouses, colleagues as well as parents' relationship with their own children. Clinical studies based on attachment theory that examine families with problems such as depression and maltreatment also acknowledge the impact of childhood attachment on adulthood issues (Bretherton 1992).

Mary Ainsworth, once a student and then Bowlby's colleague, later developed a theory of attachment behavior systems as an extension of attachment theory. While working with children in Uganda, Mary Ainsworth (1967) conducted an experiment, known as "strange situation", and identified three main groups of attachment behavior: secure, ambivalentinsecure, and avoidant-insecure. Ainsworth found that the kind of attachment formed during childhood is dependent on the availability, sensitivity and responsiveness of the caregiver figure to the needs of children (Ainsworth 1967). The secure attachment is the source of the child's sense of comfort and security. It is also the base for independence, exploring the world and developing new skills (Ainsworth 1967; Ainsworth et al. 1978; Bowlby 1951 \& 1979; Simpson \& Rholes 2010). Insecure attachment on the other hand, results in negative feelings and problematic personalities.

Pivotal to attachment theory, as discussed by both Bowlby and Ainsworth, is separation and its impacts on children. Based on his observations, Bowlby was cautious about separating children from their parents (Holmes 1993, 21). According to him, abrupt separation or deprivation of a secure attachment bond is emotionally harmful for children. More harmful than abrupt separation, as argued by Bowlby (1979), are sequences of separations and recurrent disrupted attachments. This observation is directly relevant to the case of live-in 
caregivers' children who experience at least two series of separation and disrupted emotional ties.

It is important to consider that for many youth the trauma is two-fold; they not only experience the trauma of separation from their mother but that of the second separation from the person who has cared for them in the Philippines in their mother's absence, often a maternal grandmother or aunt"(Pratt 2006, 48).

\section{Critiques of Attachment Theory}

Attachment theory influenced hospitals and orphanages treating children (Bretherton 1992). In 1951, as a contribution to the United Nations program for the welfare of homeless children, John Bowlby prepared a report for the World Health Organization (WHO). The report led to dramatic changes in public policies for those children and has received enormous approval (Bretherton 1992). However, attachment theory is also criticized from different perspectives for its limitations in terms of gender, race, class as well as cultural and social grounds in the emergence of problematic personalities (Cleary 1999; Franzblau 1991). Though the most notable volume of critiques of Bowlby belong to feminists, others also criticize him for privatizing social problems and blaming mothers as the origin of adult problems and championing children "at the expense of imposing guilt on mothers" (Tizard 1991, 183). As argued by Cleary (1999), the causes of personal distress need to be considered in their sociohistorical contexts and not in the child's relationship with mother (35). Yet according to other critics, too much emphasis on the role of mothers by John Bowlby results in neglecting the influence of other attachment figures such as fathers, siblings and especially peers in shaping the personality of children (Field 1996; Harris 1998). 


\section{Feminist Critics}

From a feministic perspective, attachment theory has been particularly criticized for prioritizing women's reproductive and child rearing abilities over their other interests and capabilities (Chodorow 1978; Franzblau 1999). Feminist scholars criticize John Bowlby for perpetuating notions of women's best role as devoted and full-time mothers, defining them as the primary caregivers in heterosexual, patriarchal and nuclear families and encouraging them to stay at home and not enter the workforce (Cleary 1999; Franzblau 1999; Theo 2005). According to its feminist critics, the theory fosters essentialist assumptions about women's natural mothering function. Within psychology, as argued by Franzblau (1999), identifying women with their reproductive role is regarded as the norm. This assumption restricts women's social life and targets their freedom. "The notion that there is some inherent glue that unites mother and child, simplifies, depoliticizes and removes from historical review the exploitative and oppressive conditions under which most women reproduce and mother" (Franzblau 1999, 29).

Attachment theory was popularized in the years after the Second World War and served a political economic purpose as well as leading to gender marginalization. During the Second World War women had entered the workforce to replace men who were in military services. After the war, due to concerns about the unemployment of returned soldiers, there were attempts to send working women back to homes (Holmes, J. 1993). Attachment theory was then presented in a way to fulfill and justify this purpose. "When theory is in the interest of those in power, policy is not far behind" (Franzbau 1999, 28). Using Bowlby's theory, different articles and books in this period highlighted the long-lasting advantages of children's secure 
attachment to their mothers and harmful outcomes of insecure attachment (Bretherton 1992; Shaffer et al. 2005). The debates heavily relied on John Bowlby's notion that security for a child is gained through being raised by the same caregiver, mainly expected to be the mother: (Bowlby 1951; 1966; 1969). But the purpose behind many of these debates was to solve the unemployment crisis through encouraging women to return home (Bretherton 1992).

John Bowlby, relying on science, assumed universal generalizability for his theory. However the language of attachment theory implies racial, gender and social class divisions. Relying on biological differences between genders, attachment theory is believed to justify differential treatments of men and women (Cleary 1999; Franzbau 1999). Similarly encouraging women to stay at home and take care of their children serves class discrimination and results in marginalizing working-class women who are always required to work despite their reproductive situation (Franzblau 1999).

Bowlby is also blamed for centralizing the role of mothers and blaming them for the problems experienced by their children. As Bretherton (1992) argues, however, most pivotal to attachment theory is an infant's need for an emotional bond with one or more sensitive and responsive caregiver and not necessarily the mother. During an interview with Southgate (1990), Bowlby himself remarked that the origins of his theory had roots in cases that leave no room for blaming mothers: Separation of infants and children from their mothers, as the result of war or illness, was related to social and historical grounds that had nothing to do with the role and responsibilities of mothers (Southgate. et al. 1990). Even though Bowlby does not blame mothers, in discussing his theory, he emphasizes the female parent and gives fathers a second role in parenting, true to notions of his time (Bretherton 1992). The centrality of 
mother-child relationship in attachment theory gives way to different criticisms and interpretations. One of these interpretations emerges from a misrepresentation of the term 'prolonged separation' as a key term in John Bowlby's statement:

If it became a tradition that small children were never subjected to complete or prolonged separation from their parents in the same way that regular sleep and orange juice have become nursery traditions, I believe that many cases of neurotic character development would be avoided (Bowlby 1940, 175).

The term "prolonged separation" as clarified by John Bowlby is "complete and prolonged separation, six months or more, from their mothers or established foster-mothers" (John Bowlby i940, 175). Elsewhere, John Bowlby (1979) argues that the absence of a mother for six months or more before the child's sixth birthday is the common experience for those who develop psychopathological depression or delinquent characteristics (71). However, as Charles Bowlby $(2004,15)$ has argued some critics misinterpreting this statement have argued that John Bowlby was against women's work outside the home. Equating the effects of prolonged separation with a few hours a day that mothers spend in their working place has been the source of confusion and misunderstanding of both John Bowlby and his attachment theory (Bowlby, C. 2004, 15).

\section{The Live-in Caregivers' Children; Prolonged and Successive Separations}

Despite the limitations of attachment theory, Bowlby's assumptions about the harmful impacts of abrupt, prolonged and successive separations are relevant to the case of live-in caregivers' children. Based on the experiments and observations of John Bowlby and Mary Ainsworth prolonged separation of children from their mothers or main caregiver figures-such as grandmothers or aunts- results in various psychological issues. Though prolonged separation 
might not be applicable to the case of parents who leave their children for several hours a day, it is directly relevant to the migrant live-in caregivers whose children are separated from them for years.

Family bonds and mothering values are strongly emphasized in Canadian society. However, live-in caregivers cannot immigrate to Canada with their families (Arat-Koc 2001, 22). The LCP is an employment program and the visa it issues for live-in caregivers is not an immigrant but rather a working visa. Lack of citizenship status, as the immediate consequence of a working visa, has the clear message of separation for live-in caregivers and their families. Live-in caregivers do not receive permanent residency upon immigration but can apply for it after 24 months or 3900 hours of approved full-time employment (Citizenship and Immigration Canada 2010). If and when they gain residency, they can sponsor their spouses and their children. The process of applying for, and gaining permanent residency takes on average three to five years (Arat-Koc 2006, Isaksen 2008). Some of live-in caregivers have already spent some years as domestic workers in other countries like Singapore, Hong Kong and Saudi Arabia before immigrating to Canada which adds to the length of separation from their children (AratKoc 2001). The long period of separation creates emotional injuries on live-in caregivers" children and affects their relationship with their mothers. During an interview with Parrenas (2005), Isabelle Tiradore remembered her experience of a prolonged separation:

When I was seven years old my mom went to Malaysia first for one to two years. Then she went to Saudi Arabia and then from Saudi Arabia she went to the U.S., that was the longest-ten years-that we didn't see each other at all. She came back and when we saw each other, I was already twenty-one years old (141). 
Separation is also a source of anxiety and sadness for the mothers who have to spend long periods far from their children (Arat-Koc 2001; Cohen 2000; Pratt 2008). A mother, who had to leave her children when one of them was an infant, describes her feeling:

As the little one grew, I spoke to him, too. But since he didn't know me, our communication was quite short. I really had to pull the words out of him (cited in Suarez-Orozco 2001, 11).

The research and studies that focus on live-in caregivers so far reveal the emotional injuries caused by separation on both live-in caregivers and their children. Separation, as experienced by live-in caregivers, is associated with guilt, regrets and heartbreaking moments of missing their children. But the children suffer more than their mothers (Parrenas 2005). According to the results of a survey conducted by Manila's Scalabrini Migration centre, the children of the migrant workers express more anger, apathy and confusion compared to their classmates (Hochschild 2003, 22). Poor school performance was also more frequent for these children. In their study Battistella and Conaco (1998) found that the children with absent mothers are more sad, angry, frustrated and apathetic compared to other groups of children. Even reports that recognize acceptable educational performances by these children admit that they face different emotional problems and "suffer an incalculable loss when a parent disappears overseas" : (Parrenas 2003, 42). Studies that have focused on the emotional well-being of these children have identified their problems as pain, anger, frustration, resentment, betrayal, vulnerability to abuses and their sense of loneliness and bewilderment (Batistella \& Conaco 1998; Parrenas 2003; Reyes 2007). These effects are standard accounts of separation trauma and anxiety (Pratt 2006). Some older children openly talk about their hurt feelings:

I want you to write about the human cost for people like us, to be apart for year after year. I'm living here in this hostel, and my classes are fine, but I can't talk to my mother. 
I can't tell her things. I can't see her face. I can't hug her. I can't help her. My mother misses me too. My mother will retire at some point, but how old will I be then? (cited in Isaksen et al. 2008, 67).

Though many children are aware of, and understand the reason behind their mothers' departure, they still feel sad and lonely (Hochschild 2007). During an interview with Parrenas (2003) Ellen Seneriches, the daughter of an immigrant domestic worker states: "I realize that my mother loves us very much. Even if she is far away, she would send us her love" (43). However she also emphasizes that:

There are times when you want to talk to her but she is not there...There are times when I want to call her, speak to her, cry to her, and I cannot. The only thing I can do is write to her. And I cannot cry through the emails and sometimes I just want to cry on her shoulder" (cited in Parrenas 2003, 42).

The contradictory sense of feeling loved but also abandoned is common among these children.

Rudy Montoya provides another example:

As I was growing up, I realized that she is the best...If she didn't work abroad I would have no hope...Before I had told you that my mother really loves me, yet you could say that my mother abandoned me (cited in Parrenas, 2010, 1854).

Marinel, a daughter of another immigrant domestic worker, shared her similar feelings:

I know she loves me because she is working hard so that we could have everything we want and everything we need. Even when she is sick she continues to work...But still I want her to be with me here every day. It's because since I was small it was only my grandparents showing me love. She was not here (Parrenas 2010, 1832).

Children of immigrant mothers develop a doubt about the reason for their mothers leaving them; "Did my mother have to leave, or she did want to leave? Or did she leave me?" (Isaksen et al. 2008, emphasis original). As mentioned by live in caregivers in different interviews, the most frequent question asked by their children is why their mothers did not take them with (Arat-Koc 2001; Ehrenrich and Hochschild 2003; Parrenas 2003 \& 2006; Pratt 2006; Suarez-Orozoco 2001). Live-in caregivers, even those who have been reunited with their 
children recognize these impacts and feel anguish while recalling the separation (Isaksen et al. 2008). The doubts about being abandoned later change to distrust. As expressed by a live-in caregiver in an interview:

The effect of separation on my children was overwhelming. My children felt insecure and unprotected while I was away. The trust on me as a parent was totally diminished by the time we got together in Canada (cited in Arat-Koc 2001, 28).

The observation of a Head Master of a boarding school for children of migrant workers, in Kerala, is in accordance with what the live-in caregivers feel:

The children we have here range in age from 5 to 16. Many of them have lost trust in adults. They are very independent, but not always in a healthy way. They distrust adults" (cited in Isaksen et al. 2008, 68).

As discussed earlier, Bowlby (1979) does not restrict attachment to a specific figure. He argues that children can keep several attachments at the same time. Similarly, the need for continuous care and parenting does not imply an exclusive mother-child relationship (Ainsworth 1962). Live-in caregivers' children also are not necessarily abandoned or neglected. Some of them receive acceptable guardianship, love and care by other members of the extended family (Hochschild 2003; Parrenas 2005). However, the inconsistency of these emotional bonds leaves long-term negative impacts on them. "A child may not require uniformity of care but he does need consistency of care. The world must be a predictable place for him, particularly where the people he sees daily are concerned" (Schaffer 1977, 105; emphasis in the original). Live-in caregivers' children sometimes experience successions of disrupted attachments and separations. The most known immediate result of a sequence of separations is a combination of intense hatred and feelings of being unloved and rejected (Bowlby 1979, 10). 
John Bowlby (1951) regards the continuity of a warm relationship between the child and the mother or a "permanent mother substitute" as critical for mental health (11). According to Bowlby (1979) discontinuity of parenting and successive separations from other caregiver . figures, to whom children develop later attachments are typical patterns that lead to anxiety and other psychiatric disorders. This pattern is clearly relevant for the children of live-in caregivers who experience separation and interrupted parenting more than once. In the absence of their mothers, these children become attached to other members of the family who take care of them. Upon reunification, the children experience another broken attachment and separation (Pratt 2006, 48). During an interview a mother describes how upon reunification, her son longed for his grandmother who had taken care of him during the years of separation:

He would say, 'Who are you?' and I would say, 'I am your mother'. And he would say, 'No you aren't my mother.' And he'd show me the pictures of my mother and say, 'She is my mother'" (Bernhard 2005, 19; emphasis in the original).

Reunification with mother, as described by an 11-year old boy meant separation from other attached and loved figures:

Once I was in the plane they told me to be calm, not to be nervous, not to cry. I was crying because I was leaving my grandfather. I had conflicting feelings. On the one side I wanted to see my mother, but on the other I did not want to leave my grandfather (cited in Suarez-Orozoc et al. 2001, 8).

The absence of live-in caregivers' children in psychological research and analysis is likely the result of racial and class hierarchies. It is also amplified by the way most modern societies regard domestic and care work (Hodge 2006). As an aspect of social reproduction, care and domestic work are crucial to reproducing people on a daily basis. But it is also a stratified concept accomplished and experienced differently by people from different races, ethnicities, genders and classes (Anderson 2001; Arat-Koch 2006; Bezanson \& Luxton 2006; Clark 2000). 
Associated with women and performed behind closed doors, domestic and care work is subject to invisibility (Ehrenreich \& Hochschild 2003). But state policies and cultural values double this invisibility while it is performed by live-in caregivers; their invisibility hides lack of state child care services. Moreover, the individualistic norms that disapprove of any help or human interdependency are highly valued and encouraged within Western societies. Following these norms, "servants are no longer displayed...but often remain in the background, or disappear when company comes" (Ehrenreich and Hochschild 2003,4). One of the significant outcomes of this culture is further marginalization of live-in caregivers and their efficient role in social reproduction.

The Live-in Caregiver Program, through its devaluation of domestic and care work, marginalizes women of all classes and races in Canada (Hodge 2006, 64). As discussed by AratKoc (2006) the neo-liberal ethics and work place expectations for employers and immigration restrictions for domestic workers, force mothers on both sides of the employer-employee relationship to "tuck their maternal roles away" (87). The final outcome of this tucking away, devaluing of domestic work, marginalizing of domestic workers and ignoring their contribution to social reproduction is the total invisibility of the children of the live-in caregivers.

\section{Attachment Theory and the Employers' Children}

Another relevant link between the LCP and the attachment theory has to do with the employers' children that live-in caregivers take care of. The work performed by live-in caregivers, besides physical labor, involves emotional and love labor (Hochschild 2003, 22). The intensive and continuous engagement between live-in caregivers and the children they take 
care of results in developing emotional ties between them (Anderson 2001; Arat-Koc 1997; Hochschild 2003; Hondagneu-Sotelo 2003; Moors 2003). Separated from their own children and living an isolated life, immigrant caregivers give their love and care to the children they take care of and take part in what Hochschild (2003) calls "a global heart transplant"(22). As an example of this emotional relationship, Hochschild (2003) describes Rowena, a caregiver who calls Noa, the baby she takes care of, "my baby". She takes her from her crib early in the morning, feeds her, entertains her, and "curls up with her for naps" (16). In the absence of her children Rowena substitutes Noa for them and feels like a mother to her.

Besides the intensive interaction between live-in caregivers and these children, the absence of parental responsibilities and mutual expectations allows both sides to enjoy the relationship in a more anxiety-free manner. As expressed by a mother, an American lawyer:

Carmen just enjoys my son. She doesn't worry whether...he's learning his letters, or whether he'll get into a good preschool. She just enjoys him. And actually with anxious busy parents like us, that's really what Thomas needs. (cited in Hochschild 2003, 24).

Far from their own children and spending long hours with their employers' children, the live-in caregivers can become so attached to these children that sometimes they prefer them to their own children:

I love Ana more than my own children. Yes, more! It's strange, I know. But I have time to be with her. I'm paid. I am lonely here. I work ten hours a day, with one day off. I don't know any neighbors on the block. And so the child gives me what I need (cited in Hochschild 2003, 24).

In some cases, the live-in caregivers find these children more attached to them than their own children who behave indifferent upon reunification. The experiences of live-in caregivers comparing their own children to their employers' ones are revealing: 
I jumped with joy when I saw my children come out of the Airport Customs. I felt all eyes on me because I must have looked like a crazy woman. I waited for them to hug me...but they did not recognize me-that was the worst feeling (cited in Arat-Koc 2001, 33).

The children I take care of give me a hug as soon as I come to work, and hug me goodbye when leave. They are much more affectionate than my own children who have joined me (cited in Arat-Koc 2001, 33-34).

Hondagneu-Sotelo (2003) describes the experience of Elvira, a live-in caregiver who, facing conflicts and pressure, leaves her employer' house: "She had only one regret: she longed to see the little boy she had cared for" (59). The experience of Celestina, another caregiver, fired by her employer, was shocking for her as "she was abruptly forced to part with the twoyear-old she had tended since birth, and whom she had grown to love" (Hondagneu-Sotelo $2003,61)$. In some cases the emotional pressure is too much for the caregivers:

I cared for a baby for his first year...the child loves you as a mother, but the mother was jealous and I was sent away. I was so depressed then. Seriously depressed. All I wanted was to go back and see him (cited in Anderson 2000, 119).

Sometimes live-in caregivers continue their relationships with these children after the end of their contract. This creates emotional conflicts between live-in caregivers and their own children after reunification. Even before reunification, live-in caregivers' separated children do not feel good about the relationship between their mothers and the children they take care of:

Very jealous. I am very, very jealous. There was even a time when she told me the children she was caring for that they are very lucky that she was taking care of them, while her children back in the Philippines do not even have a mom to take care of them. It's pathetic, but it's true. We were left alone by ourselves and we had to be responsible at a very young age without a mother. Can you imagine? (cited in Parrenas 2003, 42).

The kind of care and love that live-in caregivers give to the children they take care of, is different from what they give to their biological children (Hochschild 2003). The difference as observed by a live-in caregiver is rooted in the way she has been brought up as a child: "My 
kids, I treated them the way my mother treated me". (Hochschild 2003, 24). The quality and extension of love and attention that live-in caregivers give to the employers' children is a blend of their loneliness, their freedom from parental anxiety for these children, their longing for their own children as well as adopting a new way of expressing emotions for children (Hochschild 2003, 25). The result of this long and consistent emotional care is that the employers' children become attached to their caregivers (Ehrenreich and Hochschild 2003, 4). When live-in caregivers are fired by their employers, or leave their workplace as result of pressures or the end of their contract, this creates disrupted attachment and abrupt separation for these children. The emotional impacts of separation on these children, though much different from those of live-in caregivers' children, have not received any attention yet.

Far from their children, live-in caregivers are not able to provide them with the care and love they give to their employers' children. However, to bridge the separation they keep their emotional bonds with them through frequent phone calls and trying to remain involved in their routine of life. Sending gifts for their children is another strategy for reassuring them of their care and attention (Hondagneu-Sotelo \& Avilo 2005). However, as discussed in the following chapter, "essentialist notions of gender" (Parrenas 2010, 1844), upheld in the sending countries, mean that their transnational mothering is often not approved of. The disapproval affects live-in caregivers and their children and makes the separation more problematic for them. 


\section{Transnational Mothering and Live-in Caregivers' Children}

For immigrant live-in caregivers who are mothers, transnational mothering is "an inevitable outcome of immigration" (Parrenas 2005, 93). In countries with poor economic conditions, the choice for mothers is limited to staying with their children in desperate poverty or living apart to help them financially (Ehrenreich \& Hochschild 2003). However, for immigrant mothers, living apart from their children does not mean leaving them. Other, usually female, members of the extended family are delegated to take care of the immigrant mothers' children in the absence of their mothers. Moreover, modern technology has enabled these mothers to perform "transnational mothering" for their children despite the distance that separates them. For immigrant mothers, transnational mothering is an extension of their roles and responsibilities as mothers, but from afar (Parrenas 2010). By discussing transnational mothering, this chapter aims to explore how live-in caregivers' children, in the countries of origin, are affected by the impacts of this non-traditional version of mothering. The chapter begins by discussing transnational mothering and its role in reducing some of the negative effects of separation on both mothers and children. It then explores how gender expectations affect the perception of transnational mothering in the countries of origin and shows that the negative impacts of these perceptions on live-in caregivers' children are pivotal to their thoughts and feelings. The chapter concludes by discussing the problems these children face after reunification.

-Transnational mothering has some similarity to mothering that took place under slavery. However, while "women slaves were valued as breeders of more slaves" (hooks 1981, 15) some working class women caring for others in modern societies are being asked to forgo biological 
or social reproduction (Arat-Koc 2001, 21). The children of domestic workers, unlike the children of slave women, do not increase the employer's capital or are not seen to improve service to the employer, and so are not welcome in the employers' households. "Migrant domestic workers unlike slave women are positively discouraged from having children" (Anderson 2000, 134). In some countries like Singapore, state policies clearly require immigrant domestic workers to have a pregnancy test every six months. If pregnant, they are returned to their countries of origin (Anderson 2000; Arat-Koc 2006). The idea of single and childless domestic workers is similarly encouraged in the sending countries. In 1995, during a speech, Philippines President Fidel Ramos, though acknowledging the economic dependence of the country on the remittances sent by the immigrant live-in caregivers, also emphasized that "only single and childless women are those who are morally permitted to pursue labor migration" (cited in Parrenas 2010, 1836).

In Canada, the 'singleness' of live-in caregivers is ensured through the provisions of the $L C P$, including lack of citizenship status and the live-in requirement. The justification for this requirement is that "the demand is for live-in domestic workers and that live-out jobs in domestic works can be easily filled by workers already in Canada (Steil and England 1997, 341; emphasis is in the original). This justification, however, hides the political will for creating and maintaining a group of vulnerable workers in Canada (Arat-Koc 2003, 79). As said by the owner of a domestic employment agency: "They (employers) want a live-in to have somebody at their beck and call. They want the hours that are most difficult for them covered" (cited in Hondagneu-Sotelo \& Avila 2005, 311). As argued by Pratt (2008) live-in caregivers are brought to Canada to perform those tasks that citizens will not (7). As such, live-in caregivers represent 
the perpetuation of a racialized ideology that employs foreign immigrant women of color as doers of dirty work which the employers "are too important to do" (Anderson 2001, 28). As stated clearly, by a representative from another domestic employment agency, Canadians do not perform these kinds of tasks: "I don't think that there is a Canadian desire to be a nanny. As parents we don't raise our children to be nannies" (cited in Pratt 1997, 161). The live-in provision, besides imposing physical and emotional burden on live-in caregivers, reinforces their separation from their families. During an interview with Arat-Koc (2001), a live-in caregiver explained how her employer warned her when her visiting daughter wanted to stay in her house: "don't forget you are working" (21).

Many women who apply for the LCP do not present correct facts about their marital or parental status, as they fear that knowledge about their dependents might jeopardize their chances to be recruited for the program (Arat-Koc 2006, 78; Arat-Koc 2001, 64). However, the majority of live-in caregivers have children (Arat-Koc 2001, 22). For these mothers, the decision to leave their children is generally a very painful one. Besides handling the problems regarding their care, health, and happiness, domestic workers have "to deal with heart-wrenching feelings during separation from their children" (Arat-Koc 2006, 80). Live-in caregivers have to leave their children but they maintain their mother-child relationship through performing transnational mothering. They rearrange the meaning of motherhood and the interactions with their children to accommodate their new situation (Hondagneu-Sotelo \& Avila 2005, 308-313). Despite living apart, they remain connected and concerned about and involved with practical issues such as their children's education, nutrition and health (Parrenas 2003). As described by Isabelle, an immigrant mother's daughter: 
My mother is the one far away but she is the one who is close. It's because I think my father is there physically but he does not care. He does not get involve with us. My mother, even if she is outside the country, minds our business (cited in Parrenas 2010, 1842).

A transnational mother, involved with the lives of her children, summed up her status as; "I'm here but I'm there" (Hondagneu-Sotelo \& Avila 2005, 313). The constant communication kept by transnational mothers is regarded as key to success by some of their children:

We communicate as often as we can, like twice or thrice a week through e-mails. Then she would call us every week. And it is very expensive I know..She would give me advice whenever I had problems...She always knows when I have problems and likewise I know when she does. I am closer to her than to my father (cited in Parrenas 2003, 43).

But this is not always the case. For some children regular phone calls and receiving advice from long distance is not enough. They feel that their mothers have abandoned them and regard them responsible for their emotional and educational failures:

I talk to my mother once in a while. But what happens, whenever she asks me how I am doing, I just say okay. It's not like I am going to tell her that I have problems here...It's not like she can do anything about my problems if I told her about them. Financial problems, yes she can help. But not the other problems, like emotional problems...She will try to give advice, but I am not very interested to talk to her about things like that (cited in Parrenas, 2003, 45).

As observed by Arat-Koc(2001), mothers show concerns about the negative impacts of separation on their children and at the same time do not wish to be regarded as mainly financial providers by them. Losing emotional relationship with their children hurts immigrant mothers and leaves them heartbroken: "I think they do not miss me anymore or I don't exist. They don't care if I call or write to them" (cited in Arat-Koc 2001, 28).

Transnational mothering, as experienced by immigrant domestic workers involves hard work both physically and emotionally: 
It's terrible for us, because we are far from our children, but we are giving them food, education, we are giving them everything, although staying here you are dying because everything depends on you...(cited in Anderson 2000, 118).

Meanwhile, the ideologies associated with mothering that put much emphasis on maternal responsibility and criminalize maternal neglect result in feelings of guilt by transnational mothers (Arat-Koc 2006, 80). These mothers usually feel anxious about their children: "They might not finish their studies. They might be involved in gambling, smoking and drinking" (cited in Arat-Koc 2001, 28). They also blame themselves for any problem their children face during their absence. As expressed by one of them:

My son felt so sad. He always asked me on the phone when I will go back to the Philippines. His grades are not so good compared to before when I was the one who took care of him (cited in Arat-Koc 2001, 27).

The physical and psychological impacts of separation on live-in caregivers typically involve chronic stomach pain, muscle tension, sleeps problems, and frequent headaches and may sometimes take the form of severe anxiety and depression (Arat-Koc 2006, 81). Though immigrant mothers remain involved with their children and their problems from afar, they experience longing for them and desire to see them and take care of them closely:

When the girl that I take care of calls her mother "Mama", my heart jumps all the time because my children also call me "Mama". I feel the gap caused by our physical . separation especially in the morning, when I pack [her] lunch, because that's what I used to do for my children...lused to do that very same thing for them. I begin thinking that at this hour I should be taking care of my very own children and not someone else's, someone who is not related to me in any ay, shape, or form.... The work I do here is done for my family, but the problem is they are not close to me...Sometimes you feel the separation and you start to cry...If I had wings, I would fly home to my children. Just for a moment, to see my children and take care of their needs, help them, then fly back over here to continue my work" (cited in Parennas 2003, 41). 


\section{Stigmatization of Transnational Mothers and its Impacts on the Children}

Live-in caregivers perform a demanding job and play the dual role of caregiver and breadwinner for their children (Hondagneu-Sotelo \& Avila 2005; Parrenas 2010). However in their countries of origin they face a paradoxical situation: on the one hand, they are blamed for not investing all their time, energy and love in their children while on the other hand they are applauded for the remittances they send back. In some sending countries women are even encouraged by their own governments to immigrate because they are more reliable to send remittances than male workers (Cohen 1991; Ehrenreich and Hochschild 2003, 7). As stated by an immigrant mother:

The problem in our country is that before men emigrated. Men were going to the US, but the women were staying in the house. Then what happened was that the man emigrated and did not send anything back, he sent back no money. So the woman was a single mother with children, so if she got the chance to emigrate, she emigrated too...because she didn't have any other option to find a better future for her children. So it's terrible for her, very difficult, because they are here, they can only send money back home and their children are being brought up and cared for by another, by their relatives... (cited in Anderson 2000, 118).

Remittances are important for both families as well as for the general economy of the countries of origin. In the Philippines, for example, according to one report, between 22 to 35 million people, 34 to 54 percent of the whole population, are dependent on remittances sent by immigrant workers (Parrenas 2005, 18). The amount of money they sent to the Philippines was US\$ 6.9 billion in 1999 and more recently it has exceeded $\$ 14$ billion annually (Martinez et al. 2004; Migrante International). For this reason, the immigrant live-in caregivers are hailed as modern heroes in the Philippines (Parrenas 2005). However, the emotional consequences of the mothers' immigration are not as clear as the economic outcomes. 
Despite the significance of the remittances sent by immigrant women, there is a differentiation between mothers' and fathers' immigration. While the immigration of fathers is defined as a familial obligation for performing their responsibility as breadwinners, mothers' immigration is regarded as a neglect of their mothering duties. As a result, the children of the immigrant parents, influenced by the gender-based values, do not regard their mothers' and fathers' immigration equally. As argued by Parrenas (2005), immigrant mothers have to remind their children of their economic responsibilities and contributions, while for immigrant fathers the role is automatically assumed (132). Being a financial provider is enough to exempt fathers from other expectations and care tasks. But mothers need to prove themselves as "good providers" who nurture their children both economically and emotionally (Parrenas 2005, 135). Moreover studies show that in the absence of fathers, mothers show more flexibility in assuming the dual role of fathers and mothers. But when women are not around, men do not take up their roles, and the responsibilities are turned over to other female members of the extended family or the eldest daughter of the family (Parrenas 2010; Reyes 2007).

Both societal disapproval of transnational mothering and men's resistance to adjusting to new gender roles are reflections of a gender perspective that regards mothering as an ideology and institution (Parrenas 2003; 2005; 2010). Central to this view is the ideology of "intensive mothering" that encourages over-watchful and guilt-ridden mothers who are mainly focused on raising their children (Antler 2007; Hays 1996). The ideology of mothering assumes that women are mothers naturally and biologically. Based on this assumption, all women regardless of their race, class or culture are expected as mothers to behave the same (Rich $1986,42)$. An alternative perspective regards mothering as a fundamental aspect of social 
reproduction (Chodorow 1978; Fox 2006, 231; Green 2005; O'Reilly 2004; Rich 1986). From this perspective mothering and the parenting role in general, are not natural function but cultural constructions that vary with time, place and different historical and social necessities and . values. Based on this view, mothering affects women differently according to their race and social class (Glenn et al. 1994; Lechcier-Kimel 2007; Holmes, M. 2007; O' Reilly 2004; Zinn 2005).

Immigrant live-in caregivers clearly cannot fit into the expectations of intensive and close mothering, held strongly in both sending and receiving countries. As a result, transnational mothering of live-in caregivers is stigmatized in their countries of origin (Parrenas $2005 ; 2010)$. In the Philippines, the media, by publishing sensationalist reports, links the sufferings of children in transnational families to the immigration of their mothers and underestimates the mothering efforts of immigrant mothers (Parrenas 2003, 40). Interestingly, as Parrenas (2010) points out, there is no report on the link between these kinds of negative stories and fathers' immigration (1834). Even fathers who live with their children are not assumed responsible for the social problems of their children (Parrenas 2010, 1837). Blaming immigrant mothers for the vulnerability of their children, despite the financial contribution of these mothers to their countries, reflects the resistance of societies against redefining mothering (Parrenas 2010, 1835). Associating transnational mothering with the problems faced by their children leaves immigrant mothers with negative feelings of shame, guilt and inadequacy. It also creates a greater sense of emotional unease and insecurity for them (AratKoc 2001; Hochschild 2007; Isaksen et al. 2008; Parrenas 2005 \& 2010; Zinn et al. 2005). 
Live-in caregivers' children also face challenges associated with gendered expectations from mothers. On the one hand, they usually appreciate their mothers' efforts for providing them with good educational opportunities and better life standards. On the other hand they are affected not only by the actual impacts of separation and desire to live close to their mothers but also by the pressures of conventional ideas that stigmatize their mothers' immigration (Parrenas 2003, 49). As Parrenas $(2005 ; 2010)$ points out, the children's expectations are shaped through conventional notions of gender roles as defined within the society they live in:

What I want is, for example, what I see with other children. I see their mothers get frantic whenever they get hurt. They rush to their child's side, apply ointment on the wound. On my own, I do not get that attention. Then your mother should also brush your hair. You do that on your own without her (cited in Parrenas 2010,1832).

According to Parrenas (2010) these kinds of comments reflect "the picture of a stay-at-home mother who provides continuous care in proximity" which is the dominant image of mothers in countries like the Philippines (1833). Dominant public discourses do not challenge conventional expectations from mothers. Moreover, the fathers of these children, by sustaining their passive roles and avoiding childcare or other household responsibilities, aggravate the problems of their children (Parrenas 2010). In Canada, live-in caregivers' children are denied the attention by virtue of their race and class and the kind of job performed by their mothers. However, in their countries of origin they are subject to a different set of emotional pressures which are based on gender discrimination and stigmatize their mothers' immigration and devalue their efforts. 


\section{Reunification: the Continuation of the Problems}

If and when live-in caregivers' efforts to sponsor their families to Canada succeed, they find that this does not necessarily provide a happy ending to years of separation from their children. Reunification is not the end of problems. It rather imposes a different set of challenges and burdens on families. Uprooted from their countries of origins, many children face different challenges in the new place. As a result of long years of separation they also feel estranged from their mothers (Arat-Koc 2001). As observed by a counselor from the International Coalition to End Domestic Exploitation (INTERCEDE), and based on other similar reports, such children find it difficult to adjust to their new situations and "are likely to leave home" (Cohen 2000, 5).

For most mothers, helping their children to get over feelings of abandonment is not an easy task (Arat-Koc 2006, 83). Finding a balance between their wish to help their children, on the one hand, and to establish their authority over their children after reunification, on the other hand, is a serious challenge for these mothers. These mothers also wish to compensate for their absence. However, sometimes their overcompensation leads to aggravation of their relationship with their children: "I treat her as if she were still a baby-which she hates...Even if she is already an adult, every morning, I prepare everything on the bed for her" (cited in AratKoc 2001, 34). Mothers' efforts to establish their authority are resisted by their children who question their maternal status after years of separation. Healing the emotional wounds caused by feelings of abandonment and betrayal and undoing the distance is not an easy task for transnational mothers. As said by a live-in caregiver: "It is really hard for us to get reunited with them after a long time of separation" (cited in Arat-Koc 2001, 34). 
Live-in caregivers' children suffer maternal deprivation during separation which is followed by a material deprivation upon reunification. The remittances sent by the live-in caregivers enhance circumstances of the families and their well-being in their countries of origin. However, upon arriving in Canada they face a serious financial decline (Pratt 2006). One of the reasons for this financial decline is that, though live-in caregivers are usually university educated, the nature of what they perform as a domestic worker puts them in the process of deprofessionalization (Kelly 2009). This process affects the lives of live-in caregivers after the end of their contract as caregivers and successively upon reunification with their families. Having no other "Canadian experience" than in care work, live-in caregivers usually continue as nannies or in other low-paid, low security jobs as domestic workers (Pratt 2006).

Another challenge following reunification is that as the result of a lack of skills, language proficiency and Canadian job experience, live-in caregivers' husbands are unable to find decent jobs and end up providing cheap labour. "Rather than reunification ending the LCP experience, the LCP sets the course for families' lives in Canada, by drawing all of the family members into its orbit of social exclusion" (Pratt 2008, 7). The involvement of both parents in low-paid jobs with long working hours means both maternal and material deprivation for their children after reunification (Cohen 2000; Kelly 2009; Pratt, 2006; Velasco 2008). Sometimes, the children feel embarrassed about their mothers' jobs and keep it as a secret. As a result, they become more distanced from their mothers and the mothers feel more unappreciated (Arat-Koc 2001, 35). An additional problem is that these children face personal and systemic racism while reunited with their mothers in Canada. According to reports from Filipino-Canadian organizations many Filipino youth, mainly the children of live-in caregivers face violation of 
their rights in Canada. The violations involve a wide range from being bullied to being murdered. Among examples are the beating of Jomar Lanot at the basketball courts of Sir Charles Tupper Secondary in 2003; the shooting of 17-year-old Jeffrey Reodica by a Toronto police officer in 2004; the stabbing to death of Deeward Ponte in Vancouver's Gray Park in 2000 and 25 Filipino youth who were harassed and threatened in Vancouver Technical Secondary School by other students in 1999. According to these reports, the constant personal and systemic racism towards Filipino youth usually results in pushing them towards low paying jobs or even drug dealing and gangster activities and finally in their marginalization in Canada (Filipino-Canadian Youth Alliance National Statement 2009).

Live-in caregivers' immigration to Canada generally begins with hopes for a better future for their children. But there are often concerns about the emotional health and the general well-being of such children (Parrenas 2003; Reyes 2007). During an interview with AratKoc (2001) many caregivers expressed their concerns and worries about the future of their children. Poor prospects and security for the children of live-in caregivers after reunification make the situation more frustrating for them and the whole family (Pratt 2006, 46). 


\section{The live-in Caregivers' Children: Whose Responsibility?}

The gap between the rich countries and the poor countries is an increasing gap. According to statistics, while in 1960 the global North was twenty times richer than the South, the gap had more than doubled by 1980 (Hochschild 2003, 17). One consequence of this increasing inequality in the current global system is the movement of care workers from the global South to the global North. Due to restrictive immigration policies, one important consequence of this movement is the separation of immigrant mothers from their children. Reducing the global economic inequalities and creating job opportunities for people in their countries of origin is an ideal solution to the problems created through immigration (Hochschild 2003). Though this solution is not easily achieved, there are some possible and reasonable approaches that might help reduce the existing pressures and problems faced by immigrant mothers, such as live-in caregivers, and their children.

Addressing the impacts of separation on the children of live-in caregivers, through some insights provided by attachment theory, is useful as it sheds light on a neglected group of children who are paying the emotional cost of care demand in the First World countries. As argued by Bretherton (1992), valuing attachment relations is not only a psychological discussion. It has public implications for the society. Conducting longitudinal psychological research on live-in caregivers' children as well as the children they take care of, and transferring the results and findings to policymakers could contribute to improving the situation of live-in caregivers and their children. At the same time, however, approaching these children from a psychological perspective involves the potential risk of blaming their mothers and regarding them as the main source of their problems, which is not the case. The live-in caregivers do their 
best to ensure their children receive enough care through family members in their countries of origin, as well as through their own transnational mothering. In fact, the main reason behind their decision to immigrate is to support their children and provide them with a better future. Moreover, blaming mothers for the negative impacts of separation on their children is privatizing a problem which calls for public attention and responsibility. The well-being of live-in caregivers' children should be addressed by scholarly circles as well as by the community, state and international organizations.

\section{International Conventions, State Regulations}

At the international level, United Nations Conventions address the rights of children and immigrant workers and their families. As declared in the Universal Declaration of Human Rights "everyone is entitled to all the rights and freedoms set forth in this Declaration, without distinction of any kind" (Article 2). Similarly, the Declaration entitles the family "to protection by society and the state" (Article 16; 3). Encompassing these principles, the preamble of the UN Convention on the Rights of All Migrant Workers and Members of Their Families takes into account "the principles embodied in the basic instruments of the United Nations concerning human rights, in particular the Universal Declaration of Human Rights". Moreover in Article 64, this Convention recognizes that:

1. Without prejudice to article 79 of the present Convention, the States Parties concerned shall as appropriate consult and co-operate with a view to promoting sound, equitable and humane conditions in connection with international migration of workers and members of their families.

2. In this respect, due regard shall be paid not only to labour needs and resources, but also to the social, economic, cultural and other needs of migrant workers and members of their families involved, as well as to the consequences of such migration for the communities concerned. 
The Convention has come into force from the first of July, 2003 (United Nations). However, the 21 countries that have ratified it are mainly source countries for the immigrants. Though the majority of migrant workers live in Europe and North America, so far none of the Western, receiving countries has ratified the Convention (United Nations 2003). As a consequence, many immigrant workers, mainly engaged in low-skilled and low-paid jobs, are denied the right to live with their families in countries like Canada. The denial of this right stands against the rights of children declared in the Convention on the Rights of the Child:

The best interest of children must be the primary concern in making decisions that may affect them. All adults should do what is best for children. When adults make decisions, they should think about how their decision will affect children. This particularly applies to Budget, policy and law makers (Article 3).

In addition, the Convention declares that:

States Parties shall respect and ensure the rights set forth in the present Convention to each child within their jurisdiction without discrimination of any kind, irrespective of the child's or his or her parent's or legal guardian's race, colour, sex, language, religion, political or other opinion, national, ethnic or social origin, property, disability, birth or other status (Article 2).

Canada is among 193 countries that have ratified the Convention on the Rights of the Child (CRC). But restrictive immigration policies that are linked to the LCP impose forced separation on the children of live-in caregivers by not allowing them to immigrate to Canada with their mothers. The discriminatory character of the LCP, as argued by Bakan and Stasiulis (1994) is anomalous while viewed against Canada's recognition of gender-and race-based inequalities that are reflected in the 1982 Canadian Charter of Rights and Freedoms. It is also against societal and state discourses in Canada regarding appreciation of motherhood and parental responsibilities (Arat-Koc 2001, 24). 
At the state level, denial of the live-in caregivers' access to the same right as permanent residents and the imposition of the live-in requirement are the main restrictions in Canada that impose separation on the live-in caregivers and their children. Removing these restrictions by Canada's federal government is the basic solution for solving the separation issue. Such solution may need to involve accrediting more points to caregiving work in the point system which would enable domestic workers to immigrate to Canada with their families (Cohen 2000). Though Canada is in serious need of care work, Canadian society, like many other traditional societies, does not value care work itself or, therefore, care workers. Raising the perception of care work, perhaps through involving men, as suggested by Hochschild (2003) could be one of the solutions to this problem. These recommendations, however, as argued by Pratt (2006), would mean preventing domestic workers from applying for citizenship or even terminating the program by Canada.

The immigration of live-in caregivers without children, through the LCP, provides both Canada and the sending countries with what they need: Being separated from their family and their children, domestic workers are more probable to live in their employers' house which involves long working hours with no overtime pay. Similarly, living far from their children ensures remittances for the countries of origin. In this regard, the children of live-in caregivers are used as a guarantee for the continuation of the mutual benefits for both sending and receiving countries. In countries such as the Philippines, some advocates of migrant rights, who criticize the formation of transnational families, in fact criticize the country that uses their immigrant mothers as a short-term solution for their economic problems (Parrenas 2006). 
Similarly, scholars who conduct research on transnational families might be aware of the negative impacts of immigration on the separated children. However, some researchers fear that revealing the results of their studies may result in misjudgment or mistreating of the people they study. Feminist scholars, who value women's entry into the work force, are particularly afraid that the result of their studies could be used against immigrant women; intensify their being blamed for the problems faced by their children; and aggravate their . situation (Hochschild, 2007; Isaksen et al. 2008). Immigrant mothers are sometimes considered as a threat to traditional gender roles in the counties of origin. In this regard, any serious focus on problems faced by their children could be interpreted as an attempt to sustain those roles as well as nuclear and patriarchal families (Parrenas 2003). In this context, tackling some influential notions of gender ideology might be useful for more profound changes. The immigration of women and their new roles as breadwinners have not changed men's role in the countries of origin. In the absence of their wives they pass over the responsibilities to other female members, and sometimes the eldest daughter of the family. Assuming the role of a mother affects the girls' educational performance negatively (Parrenas 2006; 2010; Reyes 2007).

Though the volume of remittances sent by live-in caregivers is generally considered to be a definite gain for their countries of origin, some studies show that it does not necessarily improve the lives of the families nor does it help the countries to get out of poverty. These studies suggest that the utilization of these remittances should ensure a stable future for the children of the immigrant parents and serve their best interests (Reyes 2007). Addressing the issues faced by the children of live-in caregivers should not be restricted to the State. The 
policies that address these issues should be at multiple levels, involving individual, community and the nation-state. They also should cater to the needs of children at different ages (Reyes 2007; Yeoh \& Lam 2006). In the Philippines some NGOs and community based organizations intervene with the use of remittances to realize the rights of children of immigrant parents. They are also influential in the process of policymaking for these children. Through use of the media and teachers and running workshops and providing services such as individual counseling, these organizations protect and enhance the well-being of these children (Reyes 2007).

\section{Recommendations}

So far, studies that have discussed live-in caregivers and their children call for changes at the level of policy as well as social changes. Pivotal to the recommendations that address policy-makers are:

Ratifying and respecting the United Nations Convention on the Rights of All Migrant Workers and Members of Their Families by the Federal Government in Canada as well as respecting the provisions of the United Nations Convention on the Rights of the Child (Arat-Koc 2001; Parrenas 2003; Pratt2006);

Removing hierarchies of citizenship status and other immigration restrictions that result in separation of children from their immigrant mothers (Arat-Koc 2001; Bakan \& Stasiulis 1994; Hochschild 2007; Pratt 2006),

Creating job opportunities so that Immigration becomes just one, and not the only, option for people in the immigrant sending countries (Hochschild 2003; Reyes 2007). 
Other major recommendations call for changes at the wider societal level and address the NGOs, service-providers and other community-based organizations for:

Dismantling the ideology of women's domesticity and enhancing fathers' roles in care-related responsibilities (Hochschild 2003; Parrenas 2010),

Recognition of the right of working women for their motherhood arrangements (Arat-Koc 2006; Hontagneu-Sotelo and Avila 2005),

Overall improvement in the recognition of the value of domestic and care work.

The invisibility of live-in caregivers' children however is not limited to academic research and is extended to the realm of art and media too. Mainstream media is generally mute about live-in caregivers and their children. Even worse, in the cases such as in the Philippines, when they do cover them, it is horror stories or "sensational reports" that are reflected in scandalous ways (Parrenas 2003, 40). These kinds of reports that add to guilt on the part of mothers and fear and anxiety on the part of the larger society aggravate the problems faced by live-in caregivers and their children. The media and artists can, thanks to the opportunities they may have in reaching large audiences, play a role, perhaps even more efficient than academic researchers in improving visibility and developing sympathy and support for such groups. The experience of the play "Future Folk", performed at Theatre Passe Muraille in Toronto in March 2010 , is an example of such potential influence. The play is a synopsis of the live-in caregivers' predicament and displays different challenges they face in Canada and issues they have to deal with in their countries of origin. According to Catherine Hernandez, the director of the play, the majority of Canadian people who watched the play, did not know about the LCP and its 
restrictive regulations ${ }^{1}$. This type of focus on the LCP and on the experience of live-in caregivers' children by media and artists can play a vital role in creating public awareness and sensitivity and even influencing or shaping public opinion on otherwise invisible issues.

\section{Conclusion}

In recent decades, the increased participation of women in advanced industrialized countries in the labour force has created an increased need for care work which was traditionally considered as part of women's own family responsibilities. In many countries like Canada, the state does not provide the families with enough services to help with the care of children, elderly and disabled family members. This has meant that solution to the need for carework are generally privatized, and in some found in the form of hiring immigrant live-in caregivers. Immigrant live-in caregivers also do not receive support from the state for their 二-

needs for the care of family members left behind-even though the state in the countries they come from is very dependent on the contribution their remittances make to the economy. Upon immigration, these women have to rely on other female members of their families to take care of their children. One consequence of this global transfer of care and 'love' is an increased commodification of caregiving. The states in both sending and receiving countries not only abdicate their responsibilities in relation to social reproduction but also collude with one another in the exploitation of women in care-giving work. The collusion is specifically reflected in the provisions of the LCP. Though the LCP is defined as a contract between live-in caregivers and their employers, it works like an agreement between the states of Canada and the sending countries. The temporary work permit and the live-in requirement, built in the LCP, impose

\footnotetext{
${ }^{1}$ This piece of information was obtained during a personal talk with Catherine Hernandez who gave permission to be cited in this paper.
} 
family separation. This specific arrangement not only provides Canadian employers with the affordable services of a live-in caregiver beyond regular working hours and regular and a regular work, but it also guarantees the sending countries that remittances will be sent home to take care of the family members left behind. The ultimate victims of this commodified care arrangement are the children of immigrant live-in caregivers who are separated from their mothers through restrictive immigration policies and are influenced by the negative impacts of this separation.

The United Nations Convention on the Rights of the Child as well as the Convention on the Rights of All Migrant Workers and Their Families, declare that children should not be separated from their parents. However, the regulations of the LCP result in separation of children from their mothers. Far from their mothers, the children of live-in caregivers experience negative feelings of abandonment, betrayal, bewilderment, anger and sadness as well as the trauma of loss and two-fold separation. However, economic necessities, political restrictions, and cultural and social values and priorities bar an open discussion about the problems experienced by these children (Isaksen et al. 2008). The parties that are involved in the $L C P$ and receive benefits from this program, in both sending and receiving countries, are often not interested in hearing the emotional costs which are mainly paid by children (Isaksen et al. 2008). The result is the invisibility of live-in caregivers' children.

Live-in caregivers' separated children are absent not just from state policies but also from psychological research and writing, where generally children, their development and emotional experiences receive significant attention. Pivotal to these studies, and especially to attachment theory, is an emphasis on the importance of the role of a safe and continuous 
relationship between mother and child on developing healthy personalities. Attachment theory provides some useful insights regarding the harmful impacts of separation on children. However live-in caregivers' children who are separated from their mothers have not been the focus of any study from this psychological perspective. To apply attachment theory productively to the children of live-in caregivers, the theory needs to be complemented by an analysis that identifies certain structural factors that result in the negligence and invisibility of these children. According to psychology, long term separations or recurrent separations from a major caregiver might leave long lasting negative impacts on the emotional well-being of children. The children of the caregivers, though most seriously impacted by separation, may not be the only ones affected by the arrangements imposed by the LCP. As the result of their long and continuous relationship, the children who are taken care of by live-in caregivers also develop a $\checkmark$ strông attachment to them. After the end of the live-in caregivers' contract, or their dismissal by employers, the emotional ties and the experience of separation could affect these children too. Identifying the impacts of separation on both groups of children, calls for longitudinal

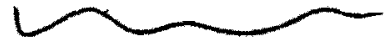
research. Yet no study in the field, to date, has focused on the children who are involved in the $L C P$. The $L C P$ is a short-term solution to the economic problems of the sending countries and the increasing demand for care in Canada. But it leaves long lasting negative impacts on different groups of people who are involved in the program.

Children have no voice in the arrangements of immigration and enforced separation but they are affected by its harmful consequences. Despite the remarkable number of children affected by immigration policies, few policies address them. The absence of children in immigration policies intensifies their invisibility. In the short term, the sufferers of the LCP are 
live-in caregivers, their families and their children, and possibly the children that they take care of. However, in the long term, their issues become a societal problem. Global economic inequalities and desperate poverty push mothers to look for better opportunities overseas and immigrate, for their children, but without them. Separated from their mothers, the children go through tough times and get hurt. Today's hurt children are tomorrow's hurt adults. A responsible society should care about the consequences of this emotional vicious cycle. 


\section{References:}

Ainsworth, M. 1962. "The effects of maternal deprivation: A review of findings and controversy in the context of research strategy". In Deprivation of maternal care, ed. Mary Ainsworth and R. G. Andry. Geneva: World Health Organization.

Ainsworth, M. 1967. Infancy in Uganda. USA: The John Hopkins Press.

Ainsworth, M., Blehar, M. C., Waters, E., Wall. S. 1978. Patterns of Attachments: A Psychological Study of the Strange Situation. Hillsdale, New Jersey: Lawrence Erlbaum Associates, Publishers.

Ally, S. 2005. "Caring about Care Workers: Organizing in the Female Shadow of Globalization". Travail, Capital et societe 38:1\&2.

Anderson, B. 2001. "Just another job? Paying for domestic work". Gender and Development Vol. 9, no. 1, March 2001. P.25-33.

Anderson, B., 2000. Doing the Dirty Work? The Global Politics of Domestic Labour. London and New York. Zed Books.

Antler, J. 2007. You Never call! You Never Write! A History of the Jewish mother. Oxford University Press.

Arat-Koc, S. 1997. "From 'Mothers of the Nation' to Migrant Workers." In Not One of the Family: Foreign Domestic Workers in Canada, ed. Abigail B. Bakan and Daiva Stasiulus. Toronto: University of Toronto Press.

Arat-Koc, S. 2001. Caregivers Break the Silence. Research coordinated by Fely Villasin, INTERCEDE. For the Rights of Domestic Workers, Caregivers and Newcomers. Canada: Q-Print.

Arat-Koc, S. 2006. "Whose Social Reproduction? Transnational Motherhood and Challenges to" Feminist Political Economy." In Social Reproduction: Feminist Political Economy Challenges NeoLiberalism, ed. Kate Bezanson and Meg Luxton. Montréal \& Kingston: McGill-Queen's University Press.

Bakan, A. B., Stasiulis, D. (Eds.). 1994. "Foreign Domestic Worker Policy in Canada and the Social Boundaries of Modern Citizenship". Science and Society. New York: Spring 1994. Vol. 58, Iss. 1.

Bakan. A. B., and Stasiulis, D. 1997. Not One of the Family; Foreign Domestic Workers in Canada. Toronto: University of Toronto." 
Batistella \& Conaco. 1998. "The Impact of Labour Migration on the Children Left Behind: A Study of Elementary School Chilrdren in Philippines". SOJURN: Journal of Social issues in Southeast Asia. 13,2, pp.220-235.

Bernhard, J., Landolt, P., \& Goldring, L., 2005. "Transnational, Multi-Local Motherhood: Experience of Separation and Reunification among Latin American Families in Canada." CERIS Working Paper No. 40

Bezanson. K., Luxton, M. 2006. "Social Reproduction and Feminist Political Economy". In Social Reproduction: Feminist Political Economy Challenges Neo-Liberalism, ed. Kate Bezanson and Meg Luxton. Montréal \& Kingston: McGill-Queen's University Press.

Bowlby, J. 1940. The influence of early environment in the development of neurosis and neurotic character. The International Journal of Psycho-Analysis, 21, 154-178.

Bowlby, J. 1951. Maternal Care and Mental Health. Geneva: World Health Organization.

Bowlby, J. 1969. Attachment and Loss: vol. 1. Attachment. New York: Basic Books.

Bowlby, J. 1979. The Making and Breaking of Affection Bonds. London: Tavistock Publications.

Bowlby. C. 2004. Fifty Years of Attachment Theory. Karnac (Books) Ltd. Bretherton, I. 1992." The origins of Attachment Theory: John Bowlby and Mary Ainsworth". Developmental Psychology, 28.

Bushnik, T., 2006. "Children and Youth Research Paper Series; Child Care in Canada". Statiscs Canada 2006. http://www.statcan.gc.ca/pub/89-599-m/89-599-m2006003-eng.pd.

Canadian Citizenship Act 2009. http://www.cic.gc.ca/english/citizenship/rules-citizenship.asp

Canadian Council for Refugees.,http://www.ccrweb.ca/documents/migrantworkers.htm.

Chodorow, N. J. 1978. The Reproduction of Mothering: Psychoanalysis and The Sociology of Gender University of California Press; Berkeley. Los Angeles. London.

Citizenship and Immigration Canada. 2010. Working Temporarily in Canada: The Live-in Caregiver Program. http://www.cic.gc.ca/english/work/caregiver/index.asp.

Cleary, R. J. 1999 III. "Bowlby's Theory of Attachment Theory and Loss: A Feminist Reconsideration". Feminism Psychology. Vol. (9) 32 http://fap.sagepub.com..

Cohen, R. 1991. "Women of Colour in White Housholds: Coping Strategies of Live-in Domestic Workers". Qualitative Sociology, Vol. 14, No. 2. 
Cohen, R. 2000. "Mom is a Stranger: The Negative Impact of Immigration Policies on the Family life of Filipina Domestic Workers". Canàdian Ethnic Studies, 00083497, 2000, vol. 32, issue 3.

Constable, N. 1999. "At Home but not at Home: Filipina Narratives of Ambivalent Returns". Cultural Anthropology , 14, 2; Research Library.

Ehrenreich, B., Hochschild, A. R. 2003. Global Woman: Nannies, maids, and sex workers in the New Economy. New York: Henry Holt and Company, LLC.

Employment and Immigration Canada 1991, 1992

Field, T., 1996. "Attachment and separation in young children." Annual Review of Psychology. No. 47.

Filipino-Canadian Youth Alliance.

ttp://www.straight.com/article-130156/filipino-canadian-youth-alliance-links-deward-pontestabbing-to-displacement\&gt.

Fox, B. 2006 "Motherhood as a Class Act: The Many Ways in which 'Intensive Mothering' is Entangled with Social Class". In Social Reproduction: Feminist Political Economy Challenges NeoLiberalism, ed. Kate Bezanson and Meg Luxton. Montréal \& Kingston: McGill-Queen's University Press.

Franzblau. S. H., 1999. "Historicizing Attachment Theory: Binding the Ties that Bind". Feminism Psychology 1999; 9:22.

Future Folk. http://www.torontolife.com/guide/arts-and-entertainment/theatre/future-folk/.

Glenn, E. N., Chang, G., and Forcey, L.R. 1994. Mothering: Ideology, Experience, and Agency. New York: Routledge.

Green, F. J. 2005. "Feminist Mothering: Challenging Gender Inequality by Resisting the Institution of Motherhood and Raising Children to be Critical Agents of Social Change". Socialist Studies. Vol 1, No. 1.

Harris, J.R., 1996. The Nurture Assumption: Why Children Turn Out the Way They do. New York: Free Press.

Hays, Sh. 1996. The Cultural Contradictions of Motherhood. New Haven and London: Yale University Press.

Hochschild, A. R. 2003. "Love and Gold". In: Ehrenreich, B., and Hochschild, A. R., Global Woman: Nannies, maids, and sex workers in the New Economy. New York: Henry Holt and Company, LLC. 
Hochschild, A., 2007. "Global Care Crisis: a Mother and Child's Eye View" http://www.gtm.cnrsbellevue.fr/site-gtm/Cla\%20Mond\%2007/Hochschild.pdf

Hodge, J., 2006. "'Unskilled Labour': Canada's Live-in Caregiver Program." Undercurrent Vol. III, No. 2.

Holmes, J. 1993. John Bowlby and Attachment Theory. Routledge.

Holmes, M. 2007. What is Gender? Sociological Approaches. London: Sage Publication

Hondagneu-Sotelo, P. 1994. Gendered Transition: Mexican Experience of Immigration. Berkeley, CA, and London: University of California press.

Hondagneu-Soetelo, P., and Avila, E. 2005. "'I'm Here, but I'm There': the meaning of Latina Transnational Motherhood". In Gender through the prism of Difference, ed. Maxine B. Zinn, Pierrette Hondagneu-Sotelo, and Michael A. Messner. New York: Oxford University Press.

Hondagneu-Sotelo 2003. "Blowups and Other Unhappy Endings". In Global Woman: Nannies, maids, and sex workers in the New Economy, ed. Barbara Ehrenreich and Arlie Russell Hochschild. New York: Henry Holt and Company, LLC.

hooks, b., 1981. in: Holmes, M., 2007. What is Gender? Sociological Approaches. London: Sage Publication.

Isaksen, L., Devi, U., \& Hochschild, A., 2008. "Global Care Crisis: Mother and Child's-eye View." Sociologia, Problemas E Practicas, No. 56.

Kelly, P. F. 2006. "Filipinos in Canada: Economic Dimensions of Immigration and Settlement". CERIS Working Paper No. 48. Toronto: Joint Centre of Excellence for Research on Immigration and Settlement

Kelly, P. F. 2009. Astorga-Garçia, M., Esguerra, E. F., and the Community Alliance for Social Justice. "Explaining the Deprofessionalized Filippino: Why Filippino Immigrants get Low-paying Jobs in Toronto". Toronto. CERIS Working Paper No. 75

Kelley, N., Trebilock, M. 2000. The Making of the Mosaic, A History of Canadian Immigration Policy. Canada: University of Toronto Press Incorporated.

Leichcier-Kimel, R. 2007. "Parënt-Child Connectedness: Moving Beyond Traditional Attachment Theory". A Major Research paper Ryerson University.

Mahon, R., 2005. "Rescaling Social Reproduction: Childcare in Toronto/Canada and Stockholm/Sweded". International Journal of Urban and Regional Research. Vol. 29 (2). June 2005 341-57. 
Martinez et al. 2004. "Another Look at the Live-in Caregivers Program: An Analysis of an Action Research Survey". Conducted .by PINAY, the Quebec Filipino Women's Association with the Centre for Applied Family Studies

Migrante International; International Alliance of Filipino migrant Organizations.

Mirchandani, K., Doucet, A.,1999. "Not one of the Family". The Canadian Review of Sociology and Anthropology. Toronto. Vol.36, Iss. 2.

Moors, A., 2003. "Migrant Domestic Workers: debating Transnationalism, Identity politics, and Family Relations". A Review Essay.

NCCYS (The New Canadian Children \& Youth Study). http://www.nccys.com/.

O'Reilly, A. 2004. From Motherhood to Mothering: The Legacy of Adrienne Rich's of Woman Born. State University of New York Press.

Parrenas, R. S. 2001. "Transgressing the Nation-State: The Partial Citizenship and 'Imagined (Global) Community' of Migrant Filipina Domestic Workers". Signs: Journal of Women in Culture and Society. Vol. 26, No. 4.

Parrenas, R. S. 2003. "The care crisis in the Philippines: Children and Transnational Families in the New Global Economy". In: Ehrenreich, B., Hochschild, A. R. 2003. (Eds.). Global Woman: Nannies, maids, and sex workers in the New Economy. New York: Henry Holt and Company, LLC.

Parrenas, S. R. 2005. Children of Global Migration; Transnational families and Gendered woes. Stanford University Press California.

Parrenas. S. R. 2006. "Understanding the Backlash: Why Transnational Families Are Considered the 'Wrong Kind of Family' in the Philippines". Asian American Studies/Sociology University of California, Davis.

Parrenas. S. R., 2010. "Transnational Mothering: A Source of Gender Conflicts in the Family." North Carolina Law Review: June 2010

Pratt, G. 1997. "Streotypes and Ambivalence: The Construction of Domestic Workers in Vancouver, British Colombia". Gender, Place \& Culture: A Journal of Feminist Geography; Jul97, Vol. 4, Iss 2.

Pratt, G. 2006. "Separation and Reunification among Filipino Families in Vancouver". Canadian Issues, Spring 2006. 